\title{
INFLUENCE OF COVER CROPPING ON WATER UPTAKE DYNAMICS IN AN IRRIGATED MEDITERRANEAN VINEYARD ${ }^{\dagger}$
}

\author{
A. TOMAZ ${ }^{1,2 *}$ (D), C.A. PACHECO ${ }^{3}$ AND J.M. COLETO MARTINEZ ${ }^{4}$ \\ ${ }^{1}$ Departamento de Biociências, Escola Superior Agrária-Instituto Politécnico de Beja. R. Pedro Soares S/N, Beja, Portugal \\ ${ }^{2}$ GeoBioTec, Universidade Nova de Lisboa, Campus da Caparica, Caparica, Portugal \\ ${ }^{3}$ Instituto Superior de Agronomia, Universidade Técnica de Lisboa, Tapada da Ajuda, Lisbon, Portugal \\ ${ }^{4}$ Escuela de Ingenierias Agrárias, Universidad de Extremadura, Badajoz, Spain
}

\begin{abstract}
As a result of its physiological characteristics, vine's yield and quality responses are greatly affected by water availability in the soil. Knowledge about water uptake of grapevines in pedoclimatic conditions of high water availability is essential when considering the increasing use of irrigation in a previously rainfed crop. We studied the water uptake of irrigated grapevines under different soil covers. The study was carried out over 2 years in southern Portugal, a Mediterranean climate region, in 'Aragonez' grapevines planted in Vertisols. A cover crop was sown in half the area while maintaining the permanent resident vegetation in the remaining area. Five levels of annual irrigation supply were applied: 200, 150, 100 and $50 \mathrm{~mm}$, and no irrigation. Soil moisture was monitored every 2 or 3 weeks, and weekly after the start of irrigation. Results show that water uptake in the interrows did not cease after the beginning of irrigation. Water uptake by the vines occurred to depths of approximately $3 \mathrm{~m}$, hence 7.5 times greater than the cover crop root system depth. Results suggest that over time, the presence of the cover crop forces the vine root system, mainly its thinner roots, to seek water in increasingly deeper soil compartments. Copyright $\odot 2017$ John Wiley \& Sons, Ltd.
\end{abstract}

KEY WORDS: cover crops; irrigation; rainfed; Vertisols; Vitis vinifera L; water extraction

Received 30 May 2016; Revised 19 December 2016; Accepted 19 December 2016

\section{RESUMÉ}

En raison de ses caractéristiques physiologiques, le rendement et les réponses qualitatives de la vigne sont grandement affectés par la disponibilité de l'eau dans le sol. La connaissance de la dynamique de l'absorption de l'eau par la vigne dans des conditions pédoclimatiques de forte disponibilité en eau est essentielle lorsque l'on considère l'utilisation croissante de l'irrigation dans une culture jusqu'à récemment pluviale. Nous avons étudié le prélèvement en eau des vignes irriguées sous différentes couvertures du sol. L'étude a été réalisée sur deux ans dans le sud du Portugal, une région avec un climat de type méditerranéen, dans les vignes de la variété 'Aragonez' (Vitis vinifera L. syn. 'Tempranillo') installées dans des vertisols. Une culture de couverture a été semée dans moitié de la zone d'étude, tout en maintenant la végétation résidente dans la superficie restante. Cinq niveaux d'irrigation annuelle ont été appliqués: 200, 150, 100 et $50 \mathrm{~mm}$, et pas d'irrigation. L'humidité du sol a été contrôlée toutes les deux ou trois semaines, et chaque semaine après le commencement de l'irrigation, avec des sondes à neutrons desservies par 63 tubes d'accès. Les résultats montrent que l'extraction de l'eau dans les interlignes n'a pas cessé après le commencement de l'irrigation. En outre, l'absorption d'eau par les vignes a eu lieu à des profondeurs d'à peu près $3 \mathrm{~m}$, donc 7.5 fois supérieures à la profondeur des racines de la culture de couverture. Les résultats suggèrent qu'au cours du temps, la présence de la culture de couverture force le système racinaire de la vigne, principalement ses racines plus fines, à chercher l'eau dans des compartiments plus profonds du sol. Copyright (C) 2017 John Wiley \& Sons, Ltd.

MOTS CLÉS: cultures de couverture; irrigation pluviale; vertisols; Vitis vinifera L; prélèvement d'eau

*Correspondence to: Professor A. Tomaz, Departamento de Biociências, Escola Superior Agrária- Instituto Politécnico de Beja. R. Pedro Soares S/N, 7800-295 Beja, Portugal. E-mail: atomaz@ipbeja.pt

${ }^{\dagger}$ Influence des cultures de couverture sur la dynamique de l'absorption de l'eau dans un vignoble méditerranéen irrigué.

\section{INTRODUCTION}

In about two-thirds of the world's wine regions, annual rainfall is less than $700 \mathrm{~mm}$ (Flexas et al., 2010). A large 
proportion of vineyards in these areas are located in the Mediterranean regions and, therefore, are subjected to a dry subtropical climate where a dry season with high temperatures coincides with most of their annual cycle of development. Among the environmental problems associated with viticulture, water scarcity during the summer is critical in countries with a Mediterranean climate (Olesen and Bindi, 2002; Laget et al., 2008; Flexas et al., 2010; Malheiro et al., 2010; Fraga et al., 2012). In Portugal, more specifically in the south regions, the traditional allocation of vineyards to less potentially productive soils is no longer practised. Today, vines also grow in more fertile soils with higher water storage capacity. Regardless of the soil's ability to support its nutritional and water demands, vines are generally irrigated. The vine is a typically Mediterranean plant, tolerant to drought. The plasticity and morphology of its root system enable exploitation of the soil and fissured geological layers up to great depths, both within and between rows (Winkler et al., 1974; Pacheco, 1989; Trambouze and Voltz, 2001; Tomaz, 2012). In fact, much of the vine's drought tolerance lies in the ability of its root system to explore the deeper layers of soil. Irrigation can contribute to obtaining higher yields, provided that a suitable irrigation schedule is adopted and appropriate amounts of water are applied. Preventing an excess of water which would promote vigour and vegetative growth, adversely affecting the quality of the wine produced, implies particular attention in monitoring water availability over certain stages of the vine growth cycle (Esteban et al., 2002; Ojeda et al., 2002; Cifre et al., 2005; Ojeda, 2007; Lopes et al., 2011). To succeed in the control of water availability one must know not only the fraction of water consumed by vines but also the soil water storage capacity, the weather conditions and the root development of the vine (Pacheco, 1989; Reynolds and Naylor, 1994; Girona et al., 2005; Tomaz et al., 2015). In addition to having other well-known advantages like improving soil structure or preventing erosion, the use of cover crops may help to restrict the vine's water uptake, inducing water restriction (Celette et al., 2005, 2008; Monteiro and Lopes, 2007; Wheaton et al., 2008; Furie, 2010; Ibáñez et al., 2010; Cruz et al., 2012; Linares et al., 2014; Tomaz et al., 2015). This is especially important in soils with high water availability resulting from their physical properties. The positive effects of cover crops in nonirrigated vineyards have been addressed in several studies, such as Afonso et al. (2003), Celette et al. (2005, 2008), Monteiro and Lopes (2007), Lopes et al. (2011) or Mercenaro et al. (2014). However, when irrigation is applied, water relations between grapevines and cover crops are likely to be modified. Taking this into account, the objectives of this study were: (i) to analyse the pattern of water uptake by the vines through their growth cycle, both within and between the plantation rows, as well as at different depths, and (ii) to assess whether the water uptake of vines is affected by depths beyond the root system of cover crops. To achieve these objectives, the water uptake from an irrigated vineyard with different cover crops was studied, and some results from previous work by Tomaz et al. (2015) regarding cover crop influence on productive responses will be addressed to better understand the results of the present study.

\section{MATERIALS AND METHODS}

The study took place in a vineyard located in the region of Baixo Alentejo, southern Portugal, during 2007 and 2008. The grapevines were of the 'Aragonez' (Vitis vinifera L. syn. 'Tempranillo') variety grafted onto SO4 rootstock, planted in 2001 , spaced at $2.8 \times 1 \mathrm{~m}$ and trained in in VSP (vertical shoot position).

The vineyard was located on undulating topography with very gentle downward slope in the direction NW-SE. The soils in the trial area were Vertisols and were called Soil I, in the higher part of the vineyard, an area of soil particle exportation, and Soil II, next to a waterline, an area of soil particle accumulation, presenting, therefore, greater depth and higher clay content. The C layer in Soil I was located at $80 \mathrm{~cm}$ depth and in Soil II at $115 \mathrm{~cm}$ depth. In both soils this layer was rich in secondary $\mathrm{CaCO}_{3}$ resulting from altered gabbrodiorites.

The total rainfall in 2007 and 2008 was, respectively, 593 and $474 \mathrm{~mm}$. The difference of about $120 \mathrm{~mm}$ was mainly due to a higher amount of autumn-winter rain during 2006/2007. The total amount of rainfall during the vinegrowing seasons was similar, 158 and $143 \mathrm{~mm}$, respectively, in 2007 and 2008.

Four test plots, each with an area of 1 ha, were defined. In two of them a cover crop was sown in November 2006 between the rows (CC plots), with a commercial grass-legume mixture, mostly rye grass (Lolium L.) and legumes (Medicago L.), and two were left with permanent resident vegetation (VE plots) with a predominance of Lolium L., although some species of Trifolium L. and Rumex L. could also be found. The plots were also distinguished by soil type (Table I). In 2008, the vegetative cover in CC plots was dominated by auto-regeneration legumes, especially alfalfa (Medicago sativa L.).

Table I. Plot description

\begin{tabular}{ll}
\hline Plot & \multicolumn{1}{c}{ Surface cover $\times$ Soil type } \\
\hline VEI & Permanent resident vegetation $\times$ Soil type I \\
VEII & Permanent resident vegetation $\times$ Soil type II \\
CCI & Permanent sown cover crop $\times$ Soil type I \\
CCII & Permanent sown cover crop $\times$ Soil type II \\
\hline
\end{tabular}


During the soil profile description, the root distribution of vines was observed. For this purpose, all the roots found in vertical planes perpendicular to the plantation row and spaced $0.50 \mathrm{~m}$ from this, were divided into five classes of diameter, as follows: $\varnothing<2 \mathrm{~mm} ; 2<\varnothing<5 \mathrm{~mm}$; $5<\varnothing<10 \mathrm{~mm} ; 10<\varnothing<20 \mathrm{~mm}$ and $\varnothing>20 \mathrm{~mm}$. These classes were colour coded and their intersections were marked in plastic wrap. Later, all the registered notes were counted using a square grid of $5 \times 5 \mathrm{~cm}$.

Within each plot, two parallel zones were identified, each with five subplots corresponding to different irrigation levels: high water comfort $(\mathrm{A}=200 \mathrm{~mm}$ annual irrigation supply); moderate water comfort $(B=150 \mathrm{~mm}$ annual irrigation supply); ultra-deficit irrigation $(C=50 \mathrm{~mm}$ annual irrigation supply); deficit irrigation ( $D=100 \mathrm{~mm}$ annual irrigation supply, matching the annual amount normally provided by the farmer). In 2008, rainfed (SE) subplots were added (Figure 1). Irrigation water was applied by an automatic drip irrigation system. The deficit and ultra-deficit irrigation treatments were conducted in accordance with the regulate deficit irrigation (RDI) strategy (Ojeda, 2007).

The experimental methodology and the effects of the vegetation cover $\times$ soil type factor on the dry biomass production of the cover crop and on the grapevines' productive responses are discussed elsewhere (Tomaz et al., 2015), where they were analysed with an ANOVA for a single factor (surface cover $\times$ soil) in the case of the surface vegetation biomass using the GLM procedures of the PASW® Statistics 18 software (SPSS Inc. ${ }^{\circ}$, IBM Corporation, New York, USA). To evaluate yield, an ANOVA for two factors (surface cover $\times$ soil type versus applied irrigation water) was performed. Differences between treatment means were compared using Tukey's test $(p<0.05)$. The statistical analysis was performed separately for each year. Table II presents some of those results, which are related to the results reported in this study.

Soil moisture status was monitored using neutron probes (TROXLER ${ }^{\circledR}$ 4300, Troxler Electronic Laboratories, Inc., Durham, NC, USA). Data from 63 access tubes were collected every 2 or 3 weeks and weekly after the irrigation start. Twelve tubes were located in the subplots of irrigation treatment $\mathrm{A} ; 11$ in treatment $\mathrm{B} ; 12$ in treatment C; 8 in treatment $\mathrm{D} ; 10$ in SE treatment. The remaining 10 tubes were distributed about equally between rows of the different subplots. The tubes were installed from 1.70 to $2.70 \mathrm{~m}$ depth, the latter being the ones located between the rows.

Based on the data collected, the soil moisture content evolution was determined and the desiccation profiles throughout the vine growth cycle were obtained. The maximum storage and maximum desiccation were defined, respectively, by the maximum and minimum profile water

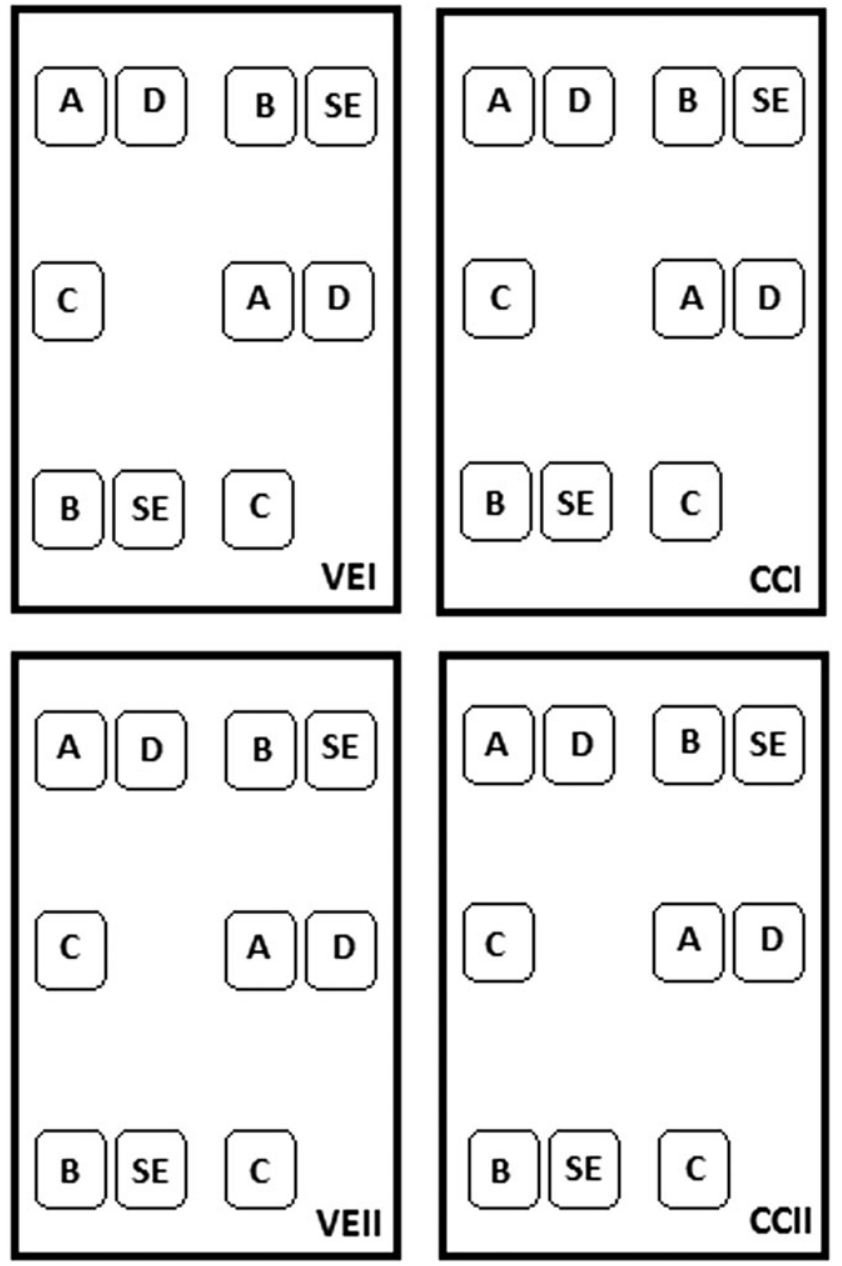

Figure 1. Experimental design (adapted from Tomaz et al., 2015): VEI = permanent resident vegetation $\times$ soil type $\mathrm{I}, \mathrm{VEII}=$ permanent resident vegetation $\times$ soil type II, CCI $=$ permanent sown cover crop $\times$ soil type $\mathrm{I}, \mathrm{CCII}=$ permanent sown cover crop $\times$ soil type II. A $=200 \mathrm{~mm}$ annual irrigation supply, $\mathrm{B}=150 \mathrm{~mm}$ annual irrigation supply, $\mathrm{C}=50 \mathrm{~mm}$ annual irrigation supply, $\mathrm{D}=100 \mathrm{~mm}$ annual irrigation supply. $\mathrm{SE}=$ rainfed.

content evaluation. The available soil water (ASW) expressed in $\mathrm{mm}$ was obtained by multiplying the volumetric water content by the depth of each layer $(30 \mathrm{~cm}$ in the surface layer and $20 \mathrm{~cm}$ in the remaining), corresponding to the measurement levels of the probes (each $20 \mathrm{~cm}$ from the surface).

The temporal evolution of ASW was obtained by computing the difference between the water content on each day and the minimum value of moisture content recorded throughout the cycle, or maximum soil desiccation.

The monthly variation of water storage in different soil zones was calculated following a methodology analogous to the one described in Celette et al. (2008). For this, six soil compartments were defined and distributed as follows: three compartments in the row, representing three layers of 
Table II. Effect of surface cover $\times$ soil type on surface vegetation biomass expressed as total dry matter, and effect of surface cover $\times$ soil type and of applied irrigation water on grapevine yield (adapted from Tomaz et al., 2015)

\begin{tabular}{|c|c|c|c|}
\hline Year & $\begin{array}{l}\text { Variation } \\
\text { source }\end{array}$ & $\begin{array}{l}\text { Total dry matter }\left(\mathrm{g} \mathrm{m}^{-2}\right) \text { of the } \\
\text { surface vegetation biomass }\end{array}$ & $\begin{array}{c}\text { Grapevine } \\
\text { yield }\left(\mathrm{t} \mathrm{ha}^{-1}\right)\end{array}$ \\
\hline \multirow[t]{11}{*}{2007} & $\begin{array}{l}\text { Surface cover } \\
\times \text { soil type }\end{array}$ & & \\
\hline & VEI & & $30.0 \mathrm{a}$ \\
\hline & VEII & & $28.8 \mathrm{ab}$ \\
\hline & CCI & $142 n s$ & $26.5 \mathrm{~b}$ \\
\hline & CCII & $179 n s$ & $27.9 \mathrm{ab}$ \\
\hline & $\begin{array}{l}\text { Applied } \\
\text { irrigation water }\end{array}$ & & \\
\hline & A & & $29.0 \mathrm{a}$ \\
\hline & $\mathrm{B}$ & & $29.4 \mathrm{a}$ \\
\hline & $\mathrm{C}$ & & $27.9 \mathrm{~b}$ \\
\hline & D & & $30.0 \mathrm{a}$ \\
\hline & Interaction & & $n s$ \\
\hline \multirow[t]{12}{*}{2008} & $\begin{array}{l}\text { Surface cover } \\
\times \text { soil type }\end{array}$ & & \\
\hline & VEI & $331 \mathrm{~b}$ & $10.8 n s$ \\
\hline & VEII & $333 \mathrm{~b}$ & $10.4 n s$ \\
\hline & $\mathrm{CCI}$ & 808 a & $10.1 n s$ \\
\hline & CCII & 838 a & $9.92 n s$ \\
\hline & $\begin{array}{l}\text { Applied } \\
\text { irrigation water }\end{array}$ & & \\
\hline & A & & $12.4 \mathrm{a}$ \\
\hline & B & & $11.1 \mathrm{a}$ \\
\hline & $\mathrm{C}$ & & $8.49 \mathrm{~b}$ \\
\hline & $\mathrm{D}$ & & $10.9 \mathrm{a}$ \\
\hline & SE & & $8.56 \mathrm{~b}$ \\
\hline & Interaction & & $n s$ \\
\hline
\end{tabular}

Different lower-case letter suffixes indicate statistically significant differences at $p<0.05$ by Tukey's test; $n s=$ no significance at $p<0.05$. $\mathrm{VEI}=$ permanent resident vegetation $\times$ soil type I; VEII $=$ permanent resident vegetation $\times$ soil type II; $\mathrm{CCI}=$ permanent sown cover crop $\times$ soil type I; CCII $=$ permanent sown cover crop $\times$ soil type II. A $=200 \mathrm{~mm}$ annual irrigation supply; $B=150 \mathrm{~mm}$ annual irrigation supply; $C=50 \mathrm{~mm}$ annual irrigation supply; $\mathrm{D}=100 \mathrm{~mm}$ annual irrigation supply; $\mathrm{SE}=$ rainfed.

soil—surface (SR), intermediate (IR) and deep (DR)—and three compartments between rows, in correspondence with the layers in the row-SBR, IBR and DBR. The surface compartments correspond to the layer $0-50 \mathrm{~cm}$, the intermediate compartments $50-100 \mathrm{~cm}$ and the deep compartments $100-200 \mathrm{~cm}$.

\section{RESULTS}

The maximum root concentration occurred at depths between 0.2 and $0.5 \mathrm{~m}$ in both soils (Figure 2), but there was a considerable difference in the proportion of thin roots in the first $0.5 \mathrm{~m}$, with Soil II presenting a much smaller amount of roots of smaller diameter, which is probably due to a structure with less macroporosity resulting from higher clay content. Smaller diameter roots had a large vertical development, and according to available data reached a depth of $2.5 \mathrm{~m}$, being able to penetrate the gabbro and diorite layer, altered and enriched in secondary $\mathrm{CaCO}_{3}$.

The medium desiccation profiles in both types of cover crop can be observed in Figure 3. Average values of volumetric water content varied between 26 and $39 \%$, both in VE and CC plots. In 2008, water content ranged from 25 to $40 \%$ in VE plots and from 26 to $39 \%$ in CC plots. Although not shown in the charts, standard deviation values ranged between $2.9 \%$ in 2007 and $3.6 \%$ in 2008. In the CC plots grapevines consumed water to depths of about $270 \mathrm{~cm}$, mainly in 2007, when precipitation was enough to supply the entire pedolithologic profile. Such is not the case in VE plots, where water uptake reached a depth of about $230 \mathrm{~cm}$ in 2007 and $170 \mathrm{~cm}$ in 2008.

The rainfall that occurred in the spring of 2007 produced an increase in the water supply in the soil profile, most evident between rows in the plots with permanent resident vegetation (Figure 4). The temporal evolution of soil available water in the rainfed treatment is very similar to the irrigated treatments. Until July, when irrigation started, the evolution pattern of water storage between rows was equal to that found within rows, either in rainfed treatments, as with 50 or $200 \mathrm{~mm}$ of annual irrigation water supply.

The comparison of water consumption in the presence of different types of vegetation cover between rows in six soil compartments is shown in Figure 5. Considering the similarity of the temporal evolution of soil available water in irrigated and rainfed treatments, in this analysis we chose to focus on data obtained in the latter where the effect of the cover crops on the water uptake of the grapevines in the various soil compartments is more evident. The water uptake is higher in the row compartments, as can be seen by comparing Figures 5(a) and (b), 5(c) and (d), 5(e) and (f). In general, as an effect of the spring rains, there is a positive variation between the months of March and April.

In 2008, almost all compartments in the sown cover crop plots showed desiccation from March to August. The influence of the cover crop is notorious in the layers between rows in 2008. The decrease in moisture content was higher during the initial months. Then, once the vegetation was cut, desiccation was slower. This dynamic was most evident in the SBR compartment. In fact, this is the compartment where the water consumption of the cover crop takes precedence, since its root system reaches a depth of about $40 \mathrm{~cm}$, although the higher density of roots is situated in the first $20 \mathrm{~cm}$. In the deep compartments-DR and DBR-a more pronounced reduction in the soil water content was observed 

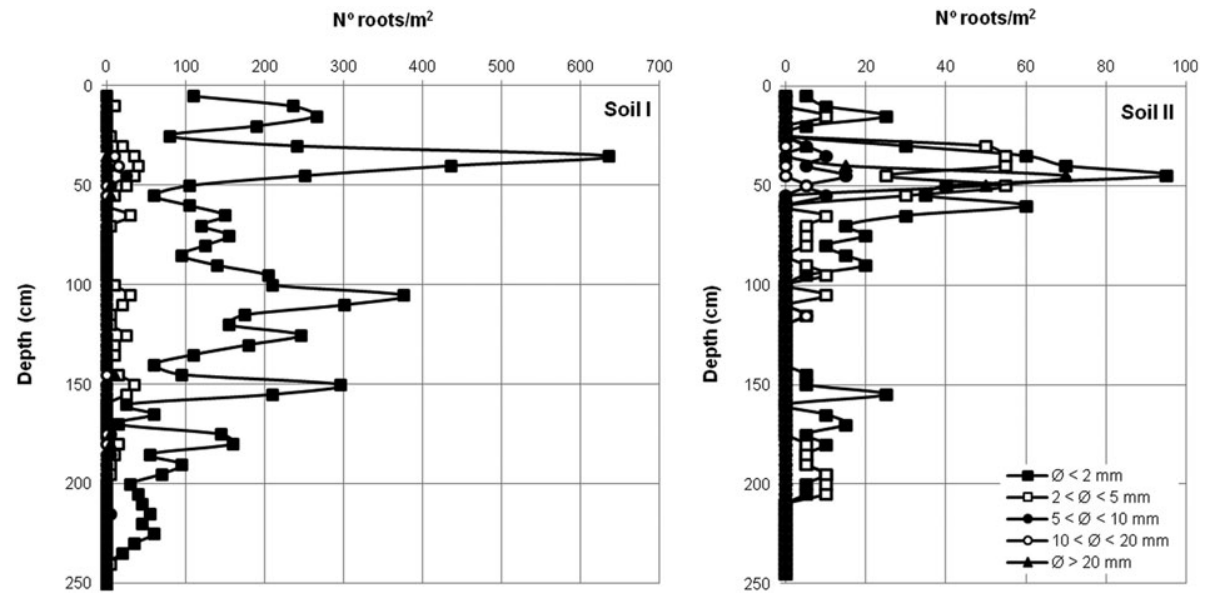

Figure 2. Vine root distribution by diameter classes in vertical planes perpendicular to the rows in soils I and II.

in 2007 (Figures 5e and f). In 2008, as a result of a lower water supply, the profile desiccated faster, as can be seen when comparing the bars of June and July. However, variations in-between rows with a sown cover crop are not so different, indicating a better supply of water in these layers as a result of increased infiltration of rainwater.
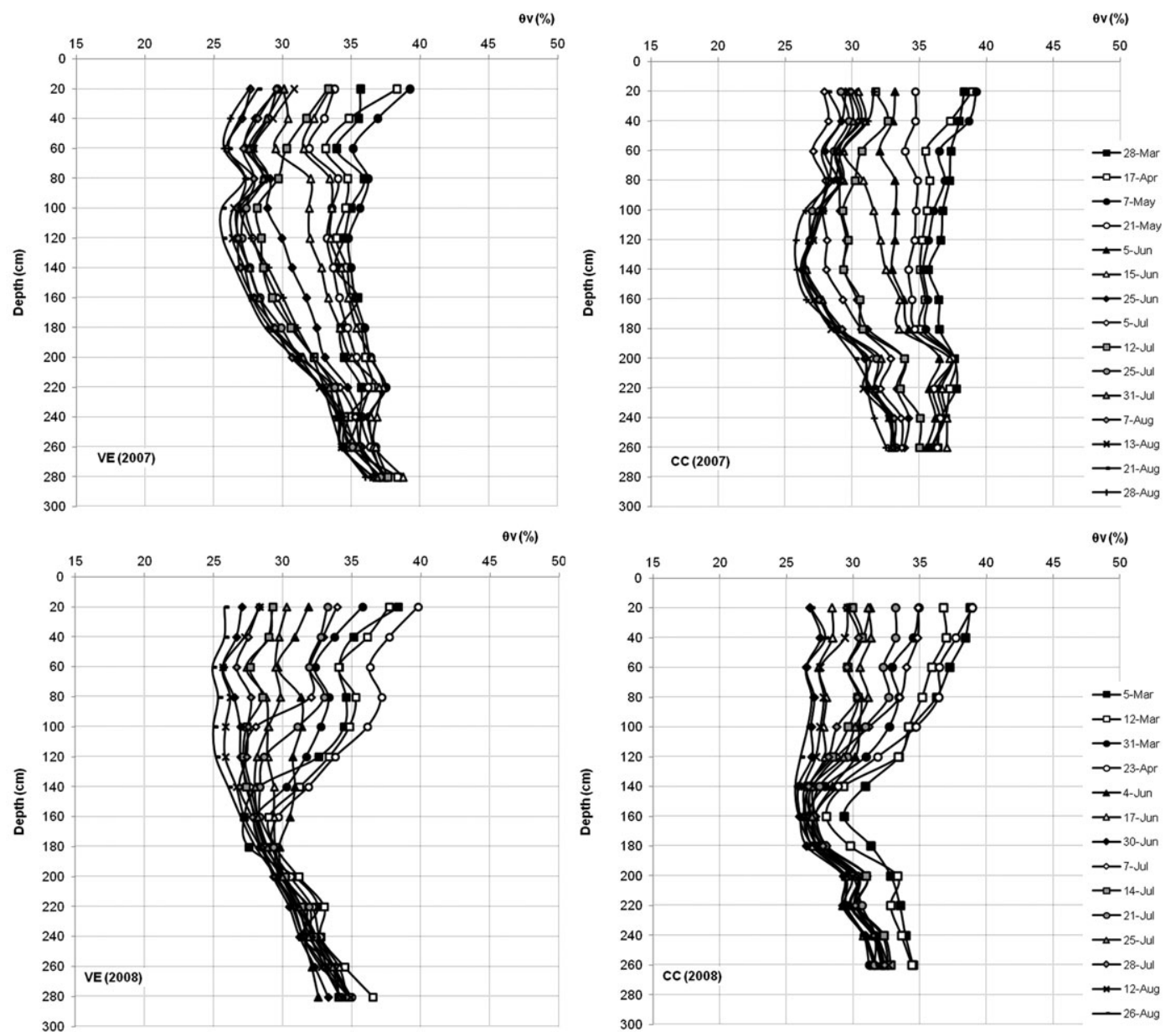

Figure 3. Average profiles of soil desiccation in the different types of vegetation cover between rows: $\mathrm{VE}=$ permanent resident vegetation, $\mathrm{CC}=$ permanent sown cover crop. 

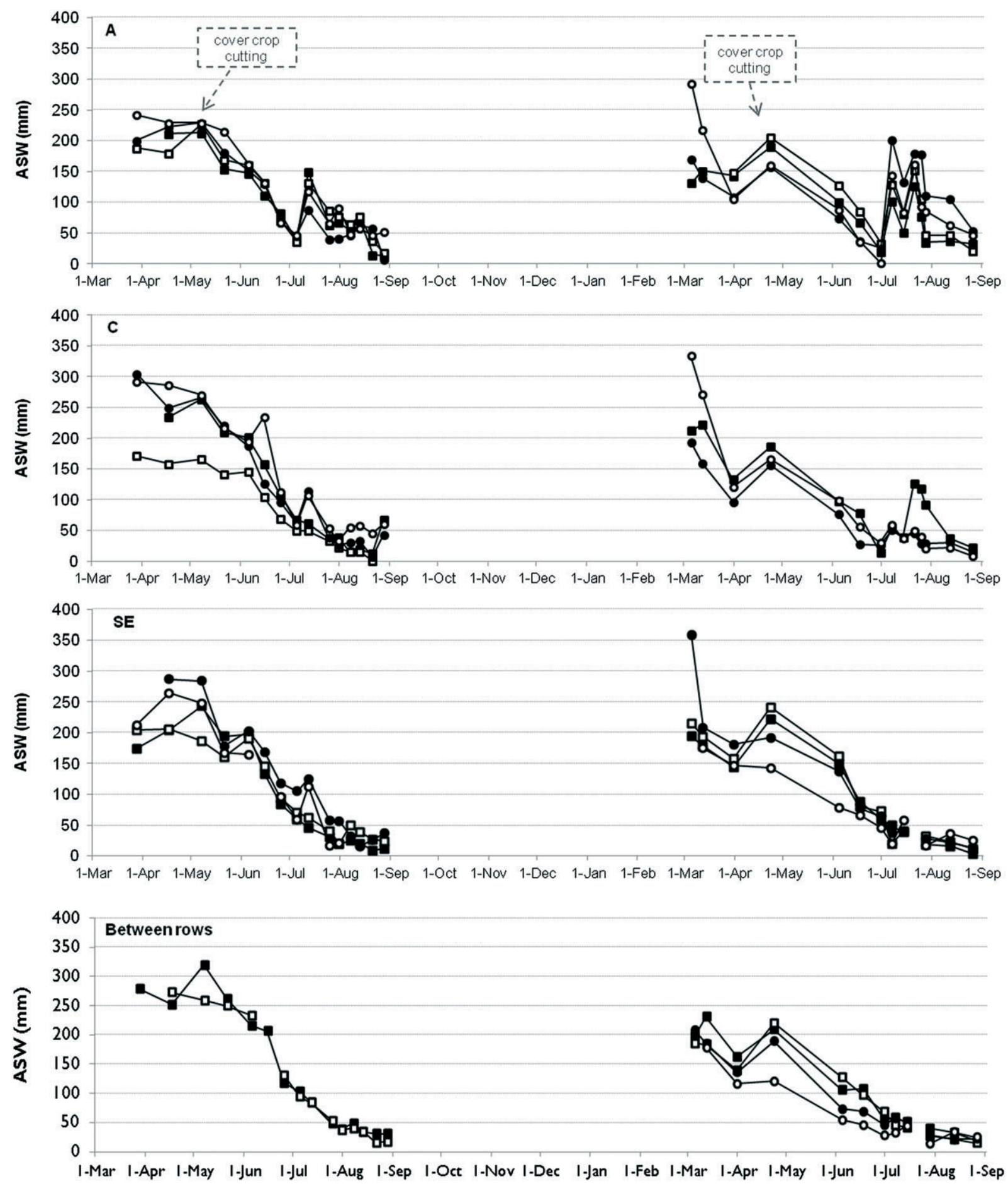

$\rightarrow-V E I \rightarrow-V E I I \rightarrow C C l \multimap-C C I I$

Figure 4. Average values of soil available water over the growth cycle in the four plots, for irrigation treatments A, C, SE and between rows: VEI $=$ permanent resident vegetation $\times$ soil type I, VEII $=$ permanent resident vegetation $\times$ soil type II, CCI $=$ permanent sown cover crop $\times$ soil type I; CCII $=$ permanent sown cover crop $\times$ soil type II. A = $200 \mathrm{~mm}$ annual irrigation supply; $\mathrm{C}=50 \mathrm{~mm}$ annual irrigation supply. $\mathrm{SE}=$ rainfed. 

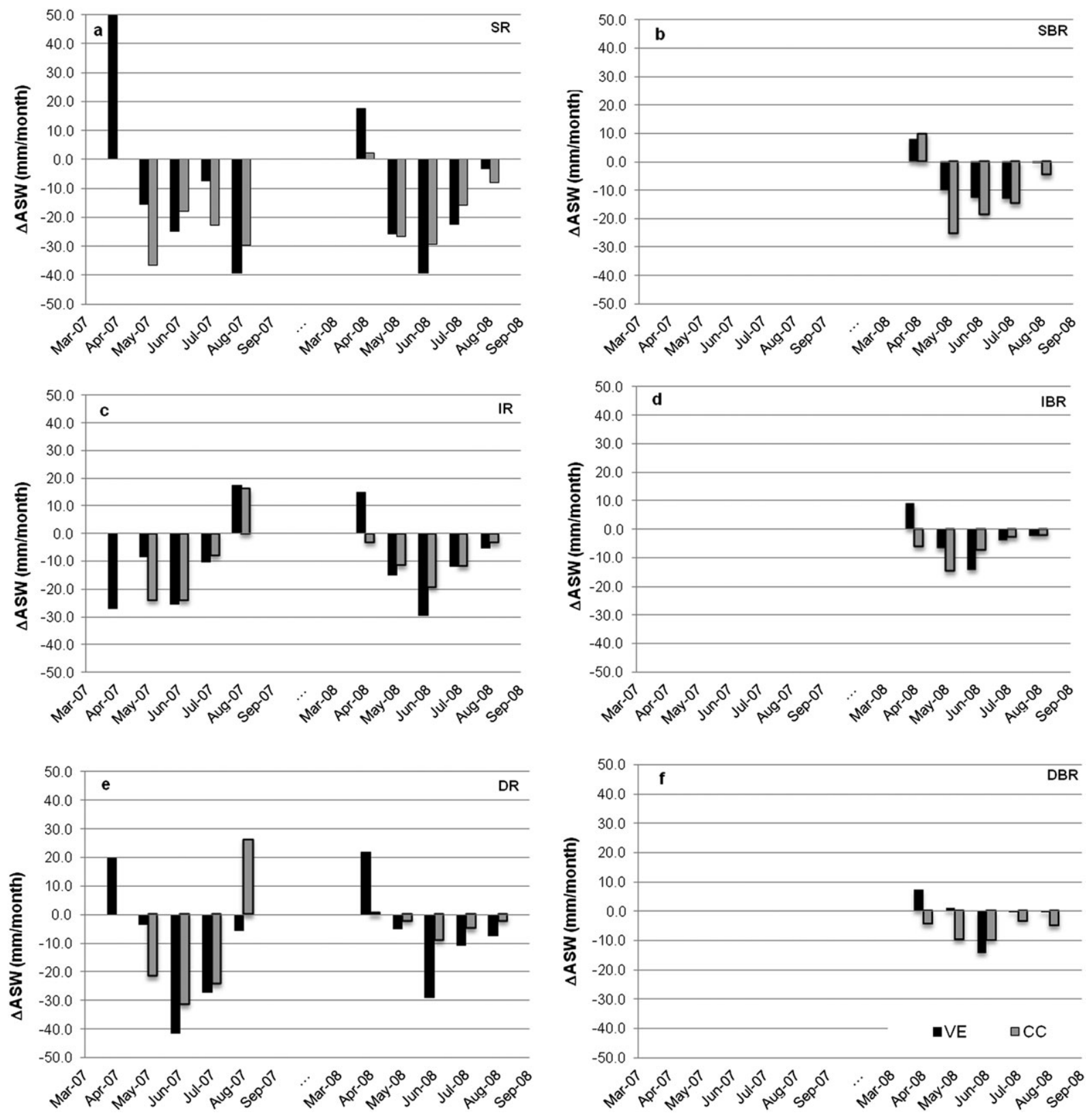

Figure 5. Monthly variation of the water content in rainfed subplots in six soil compartments: $\mathrm{a}=0-50 \mathrm{~cm}$ layer in the row, $\mathrm{b}=0-50 \mathrm{~cm}$ layer between rows, $\mathrm{c}=50-100 \mathrm{~cm}$ layer in the row, $\mathrm{d}=50-100 \mathrm{~cm}$ layer between rows, $\mathrm{e}=100-200 \mathrm{~cm}$ layer in the row, $\mathrm{f}=100-200 \mathrm{~cm}$ layer between rows. Each column corresponds to the average value of both soils in each type of vegetation cover. $\mathrm{VE}=$ permanent resident vegetation, $\mathrm{CC}=$ permanent sown cover crop.

\section{DISCUSSION}

When the soil had available water, the plants located in the plots with a sown cover crop consumed water at depths of about $3 \mathrm{~m}$. Also, the amount and intra-annual rainfall distribution along with the cover crop biomass production influenced the productive capacity of grapevines when soil water storage was lower. As is typical of Mediterranean conditions, the desiccation front advances with depth as we approach ripening, and water uptake in the deeper layers gains importance over time. The contribution of these layers to the water supply of grapevines increases with the decreasing amount of water in the soil pores of both A and B horizons, and therefore increases the activity of the thinner roots of the year, developing and occupying the soil fissures. In 2008, in CC plots, the highest moisture content values recorded were found on 5 March and not on 23 April, contrary to what happens in VE plots. Given the biomass production difference between the two types of vegetative cover that year, it appears that there is an effect of water consumption performed 
by the cover crop during the month of April. The water uptake occurred up to 7.5 times the depth of the cover crop root system (approximately $40 \mathrm{~cm}$, with the larger density of roots at $20 \mathrm{~cm}$ depth). Over time, the cover crop made its influence felt by forcing the vine root system to seek available water at progressively deeper soil layers. The gradual drying of the surface horizons, through the influence of the cover crop, forced the vines to colonize other soil horizons faster.

The observed evolution pattern of water storage between rows was similar to that seen in the rows, especially until the start of irrigation. While the cover crop develops, the water extraction of vines will be higher at greater depths, where competition with the cover crop is not felt. After the vegetation cover is cut, grapevines continue water uptake between rows throughout their annual development cycle. As mentioned above, vine root structure is formed with different diameters. The thicker roots are distributed in the soil volume nearest the stem, and the smaller diameter ramifications explore the soil in accordance with the diameter of the macropores of the horizons or layers. In Vertisols, with cracking in the summer followed by winter closing, the presence of perennial roots contributes to the determinism that regulates the opening of cracks. In lithological layers of very high bulk density, the number, diameter and continuity of macropores is limited. In these layers there are more thin roots, the entry of which into activity (water absorption) is determined by the partial drying of the topsoil, which increases air diffusion between the surface and the deeper layers. The redistribution of the root system of species in competition for a given resource was termed by Miller (1986) as 'compensatory growth'. In the case of vines, this mechanism is related to the plasticity of its roots and their ability to exploit the deeper layers, as the superficial layers dry. The greater the number of discontinuities, or the ability of the soil material to crack, the greater the number of roots and the higher the wetting (in winter) and the drying of the soil (in summer). The attraction of water in the vicinity of the roots is limited in this type of pedolithologic profile because, although high, microporosity has a very small average diameter of pores, increasing the resistance to water movement. In this context, it is likely that roots grow towards the moist zones, making it through the microfissures opened by soil desiccation.

In the deeper soil layers, the decrease in the amount of water depends on the rainfall regime verified through the year. As advocated by Celette et al. (2008), cover crops can have two functions, apparently opposite. First, during the rainy season, they promote the reduction of runoff by providing an increased amount of water stored in the soil profile, especially between the rows. Second, because most of their development cycle takes place before the start of the vine-growing season, they take precedence in water consumption in the surface layers between rows.

\section{CONCLUSIONS}

Vines located in plots with a sown cover crop consume water at depths of about $3 \mathrm{~m}$, provided that the soil profile has sufficient moisture. Over time, the cover crop exerts its influence, forcing the vine root system to seek available water at progressively deeper soil layers.

Despite irrigation, water uptake by the vines is not limited to the plantation row. In this type of soil, water uptake between rows occurs continuously throughout the development cycle of the vine. Although this takes place preferably in the surface layers of the rows, where the majority of its perennial root system is located, the thin roots of the year adjust their growth and activity as a function of available water in the different soil compartments, defined by its depth and location within the row or in-between rows.

These findings are important, taking into consideration the success of deficit irrigation strategies on the control of water availability for grapevines, especially when they are irrigated and grown in soils with high water storage capacity.

\section{ACKNOWLEDGEMENTS}

The authors wish to thank the team members of PEDIZA II (Desenvolvimento Integrado da Região de Alqueva) project Rega Deficitária em vinha-Critérios de condução da vinha compatíveis com a qualidade da Produção, financed by the IV Priority Axis of the European Union.

This work is a contribution to the Project UID/GEO/ 04035/2013, funded by FCT - Fundação para a Ciência e a Tecnologia, Portugal.

\section{REFERENCES}

Afonso JM, Monteiro AM, Lopes CM, Lourenço J. 2003. Enrelvamento do solo em vinha na região dos vinhos verdes. Três anos de estudo na casta 'Alvarinho'. Ciência e Técnica Vitivinícola 18: 47-63.

Celette F, Wery J, Chantelot E, Celette J, Gary C. 2005. Belowground interactions in a vine (Vitis vinifera L.)-tall fescue (Festuca arundinacea Shreb.) intercropping system: water relations and growth. Plant and Soil 276: 205-217. DOI:10.1007/s11104-005-4415-5.

Celette F, Gaudin R, Gary C. 2008. Spatial and temporal changes to the water regime of a Mediterranean vineyard due to the adopting of cover cropping. European Journal of Agronomy 29: 153-162. DOI:10.1016/j. eja.2008.04.007.

Cifre J, Bota J, Escalona JM, Medrano H, Flexas J. 2005. Physiological tools for irrigation scheduling in grapevine (Vitis vinifera L.). An open gate to improve water-use efficiency? Agriculture. Ecosystems and Environment 106: 159-170. DOI:10.1016/j.agee.2004.10.005.

Cruz A, Botelho M, Silvestre J, Castro R. 2012. Soil management: introduction of tillage in a vineyard with a long-term natural cover. Ciência e Técnica Vitivinícola 27: 27-38.

Esteban MA, Villanueva MJ, Lisarrague JR. 2002. Relationships between different berry components in Tempranillo (Vitis vinifera L.) grapes from irrigated and non-irrigated vines during ripening. Journal of the Science of Food and Agriculture 82: 1136-1146. 
Flexas J, Galmés J, Gallé A, Gulías J, Pou A, Ribas-Carbo M, Tomàs M, Medrano H. 2010. Improving water-use-efficiency in grapevines: potential physiological targets for biotechnological improvement. Australian Journal of Grape and Wine Research 16: 106-121. DOI:10.1111/ j.1755-0238.2009.00057.x.

Fraga H, Malheiro AC, Moutinho-Pereira J, Santos JA. 2012. An overview of climate change impacts on European viticulture. Food and Energy Security 1(2): 94-110.

Furie JC. 2010. Soil management in the Breede River Valley wine grape region, South Africa. 1. Cover crop performance and weed control. South African Journal of Enology and Viticulture 31: 14-21.

Girona J, Gelly M, Mata M, Arbonés A, Rufat J, Marsal J. 2005. Peach tree response to single and combined deficit irrigation regimes in deep soils. Agricultural Water Management 72: 97-108. DOI:10.1016/j. agwat.2004.09.011.

Ibáñez S, Pérez JL, Peregrina F, García-Escudero E. 2010. Incidencia de las cubiertas vegetales en la calidad del mosto y del vino. Vida Rural. 305. http://www.vidarural.es/articulos-incidencia-cubiertas-vegetales-calidaddel-mosto-y-del-vino/1/1237.html (accessed 12.03.15).

Laget F, Tondut JL, Deloire A, Kelly MT. 2008. Climate trends in a specific mediterranean viticultural area between 1950 and 2006. Journal international des sciences de la vigne et du vin 42(3): 113-123.

Linares R, De La Fuente M, Junquera P, Lissarrague JR, Baeza P. 2014. Effects of soil management in vineyard on soil physical and chemical characteristics. In BIO Web of Conferences, 37th World Congress of Vine and Wine and 12th General Assembly of the OIV (Part 1), at Mendoza, November; vol. 3, 1008 pp. DOI: 10.1051/bioconf/ 20140301008

Lopes CM, Santos TP, Monteiro A, Rodrigues ML, Costa JM, Chaves MM. 2011. Combining cover cropping with deficit irrigation in a Mediterranean low vigor vineyard. Scientia Horticulturae 129: 603-612. DOI:10.1016/j.scienta.2011.04.033.

Malheiro AC, Santos JA, Fraga H, Pinto J. 2010. Climate change scenarios applied to viticultural zoning in Europe. Climate Research 43: 163-177. DOI:10.3354/cr00918.

Mercenaro L, Nieddua G, Pulinab P, Porquedduc C. 2014. Sustainable management of an intercropped Mediterranean vineyard. Agriculture, Ecosystems and Environment 192: 95-104. DOI: https://doi.org/ 10.1016/j.agee.2014.04.005
Miller DE. 1986. Root systems in relation to stress tolerance. HortScience 21: 963-970.

Monteiro A, Lopes CM. 2007. Influence of cover crop on water use and performance of vineyard in Mediterranean Portugal. Agriculture, Ecosystems and Environment 121: 336-342. DOI:10.1016/j.agee.2006.11.016.

Ojeda H. 2007. Riego cualitativo de precisión en la vid. Revista Enologia 6: $14-17$.

Ojeda H, Andary C, Kraeva E, Carbonneau A, Deloire A. 2002. Influence of pre- and postveraison water deficit on synthesis and concentration of skin phenolic compounds during berry growth of Vitis vinifera cv. Shiraz. American Journal of Enology and Viticulture 53: 261-267.

Olesen JO, Bindi M. 2002. Consequences of climate change for European agricultural productivity, land use and policy. European Journal of Agronomy 16: 239-262. DOI:10.1016/S1161-0301(02)00004-7.

Pacheco CA. 1989. Influência de técnicas de não mobilização e de mobilização sobre aspectos estruturais e hídricos de solos com vinha, bem como sobre o respectivo sistema radical. Consequências das relações hídricas solo-vinha na produção. Dissertation, Instituto Superior de Agronomia, Universidade Técnica de Lisboa, Lisbon, Portugal; 1-423.

Reynolds AG, Naylor AP. 1994. 'Pinot noir' and 'Riesling' grapevines respond to water stress duration and soil water-holding capacity. Horticultural Science 29: 1505-1510.

Tomaz A. 2012. La alimentación hídrica de la variedad Aragonez (Vitis vinifera L.) en vertissuelos regados, con y sin cultivo de cobertura: efectos del riego en la producción y en la dinámica de extracción de agua. Dissertation, Universidad de Extremadura, Badajoz, Spain; 1-196.

Tomaz A, Coleto Martinez JM, Pacheco CA. 2015. Yield and quality responses of 'Aragonez' grapevines under deficit irrigation and different soil management practices in a Mediterranean climate. Ciência e Técnica Vitivinicola 30 (1): 9-20. DOI: https://doi.org/10.1051/ctv/20153001009

Trambouze W, Voltz M. 2001. Measurement and modelling of the transpiration of a Mediterranean vineyard. Agricultural and Forest Meteorology 107: 153-166. DOI:10.1016/S0168-1923(00)00226-4.

Wheaton AD, McKenzie BM, Tisdall JM. 2008. Management to increase the depth of soft soil improves soil conditions and grapevine performance in an irrigated Vineyard. Soil and Tillage Research 98: 68-80. DOI:10.1016/j.still.2007.10.007.

Winkler AJ, Cook JA, Kliewer WM, Lider LA. 1974. General Viticulture revised and enlarged ednp. LondonUniversity of California Press. 